\title{
Analisis Musik Iringan Lagu Aneuk Yatim Ciptaan Rafly Kande
}

\author{
Haria Nanda Pratama' ${ }^{1}$ Abdul Rozak ${ }^{2}$, Rico Gusmanto ${ }^{3}$ \\ ${ }^{1}$ Program Studi Teater, Institut Seni Budaya Indonesia Aceh, Aceh Besar, Aceh, Indonesia. \\ 2,3 Program Studi Seni Karawitan, Institut Seni Budaya Indonesia Aceh, Aceh Besar, Aceh, Indonesia. \\ ${ }^{(*)} \bowtie$ (e-mail) harianandapratama@isbiaceh.ac.id ${ }^{1}$, abdulrozak@isbiaceh.ac.id ${ }^{2}$, ricogusmanto@isbiaceh.ac.id ${ }^{3}$
}

\begin{abstract}
Abstrak
Lagu Aneuk Yatim merupakan karya musik bergenre pop ciptaan Rafly pada tahun 1999 yang menceritakan tentang keadaan sosial kehidupan anak-anak di Aceh terkait peristiwa konflik dan tsunami di tahun 2004, dan mencapai puncak popularitasnya baik secara lokal maupun nasional. Lagu Aneuk Yatim memiliki penggunaan instrumen dan harmoni iringan yang khas dalam kalimat lagu dengan harmoni iringan dan tangganada konvensional (background harmony). Hal tersebut menjadi rangkaian pendukung melodi yang dimainkan untuk menciptakan kesan dan pesan pada lagu. Penelitian ini mencoba untuk menguraikan dan mengidentifikasi penggunaan instrumen musik dan harmoni iringan pada lagu Aneuk Yatim, yang nantinya bisa dijadikan rujukan bagi peneliti dalam menganalisis karya musik lagu. Penelitian ini menggunakan pendekatan kualitatif dengan metode analisis deskriptif. Selanjutnya, pendekatan yang dilakukan untuk mempermudah pencarian data dilakukan dengan etik dan emik agar tercapainya kelancaran dalam proses pencarian sampai dengan pengelolaan data untuk mengindentifikasi penggunaan instrumen musik dan harmoni iringan pada lagu Aneuk Yatim. Metodologi yang dilakukan dalam penelitian ini adalah pengumpulan data yang terkait subjek maupun objek dengan cara berinteraksi langsung melalui dokumentasi, observasi, dan wawancara dengan partisipan. Penggunaan instrumen dalam lagu Aneuk Yatim terdiri dari accoustic guitar, keyboard, electric bass, dan drum set. Instrumen acoustic guitar, keyboard, dan electric bass merupakan instrumen melodis dan instrumen harmonis yang digunakan sebagai instrumen dalam memainkan melodi pada interlude, serta instrumen harmonis yang memainkan akor sebagai iringan pada melodi pokok. Harmoni iringan dan tangganada pada lagu Aneuk Yatim ini, seperti tangganada minor asli maupun minor harmonis, serta harmoni yang dipakai seperti akor I-IV-V (G-C-D).
\end{abstract}

Kata kunci: musik, instrumen, harmoni iringan, aneuk yatim, rafly kande. 


\begin{abstract}
Aneuk Yatim song is a musical work of the pop genre created by Rafly in 1999 which tells about the social conditions of children's lives in Aceh related to the conflict and tsunami in 2004, and reached the peak of its popularity both locally and nationally. Aneuk Yatim song has a distinctive use of instruments and accompaniment harmony in song sentences with conventional accompaniment and background harmony. This becomes a series of supporting melodies that are played to create an impression and message in the song. This study tries to describe and identify the use of musical instruments and the accompaniment of harmony in the Aneuk Yatim song, which can later be used as a reference for researchers in analyzing song music. This study uses a qualitative approach with descriptive analysis method. Furthermore, the approach taken to facilitate data retrieval is carried out ethically and emic in order to achieve smoothness in the search process to data management to identify the use of musical instruments and the accompaniment of harmony in the Aneuk Yatim song. The methodology used in this study is the collection of data related to subjects and objects by interacting directly through documentation, observation, and interviews with participants. The use of instruments in Aneuk Yatim's song consists of acoustic guitar, keyboard, electric bass, and drum set. Acoustic guitar, keyboard, and electric bass are melodic and harmonic instruments that are used as instruments to play the melody in the interlude, as well as harmonic instruments that play chords as accompaniment to the main melody. The accompaniment and scale harmony in this Aneuk Yatim song, such as the original minor scale and harmonic minor, as well as the harmonies used such as the I-IV-V (G-C-D) chord.
\end{abstract}

Keywords: music, instrument, accompaniment harmony, aneuk yatim, rafly kande

\title{
(c) (2)
}

This work is licensed under a Creative Commons Attribution-ShareAlike 4.0 International License. Copyright (c) 2021 Haria Nanda Pratama, Abdul Rozak, Rico Gusmanto

\section{Proses Artikel}

Diterima 08-06-2021; Revisi 21-06-2021; Terbit Online 24-06-2021 


\section{Pendahuluan}

Musikologi merupakan suatu cabang ilmu yang mengkaji atau menganalisis sebuah karya seni musik secara akademis untuk mengembangkan pengetahuan dan wawasan baik secara teori maupun konsep. Teori dan istilah yang digunakan dalam cabang ilmu ini mengacu pada perspektif ilmu musik Barat. Istilah musikologi yang berarti ilmu musik yang dalam bidang penelitian bersifat heterogen, dimana musikologi tidak hanya berkaitan dengan musik seni barat namun juga semua musik rakyat dan non-Barat. Menurut Chrysander (Indrawan, 2018) menyatakan ruang lingkup musikologi meliputi studi historis dan berbagai fenomena musik yang terdiri dari: (1) bentuk dan notasi musik, (2) kehidupan komposer dan pemain, (3) pengembangan alat musik, (4) musik teori (harmoni, melodi, ritme, mode, skala, dll.), (5) bidang-bidang estetika, akustik, dan fisiologi suara, telinga, serta tangan. Artinya musikologi menjadi sebuah teori musik barat dalam membedah, menganalisis, dan mengkaji unsur-unsur musik barat, seperti penggunaan instrumen iringan musik serta pergerakan akor yang dipakai pada sebuah karya seni musik seperti lagu (Elpasa et al., n.d.; Ferdian et al., 2021; Firnandez et al., 2014; Ghazali \& Syahrani, n.d.; Mahendra et al., 2016; Walidaini, 2020; Widyanta, 2018).

Penggunaan instrumen dan pergerakan akor dalam iringan musik pada sebuah lagu merupakan bagian dari background harmony. Penggunaan instrumen tersebut meliputi alatalat musik yang digunakan sebagai pengiring melodi atau lagu. Alat-alat tersebut biasanya terdiri dari alat musik melodis, harmoni, dan perkusi (Ferdian et al., 2021; Johnson et al., 2014). Sedangkan pergerakan akor adalah pemakaian tangganada serta isian perjalanan akor yang dipakai dalam mengiringi melodi ataupun lagu. Pemakaian tangganada seperti adanya scale yang menentukan jenis sebuah tangganada. Artinya, background harmony yang meliputi penggunaan instrumen dan pergerakan akor merupakan bagian dari struktur dan bentuk pada sebuah lagu, salah satunya lagu Aneuk Yatim yang diciptakan Rafly Kande pada tahun 1999.

Lagu Aneuk Yatim adalah sebuah karya musik bergenre pop yang diciptakan oleh Rafly Kande (Abdul Rozak et al., 2020; Frianto, 2012; Lestari, 2019; Rozak et al., 2021). Lagu ini mencapai puncak popularitasnya empat tahun setelah diproduksi bertepatan pada saat setelah bencana tsunami yang melanda Aceh tahun 2004. Dimana lagu ini mempresentasikan kondisi sosial masyarakat di Aceh terutama anak-anak pada masa konflik. Secara harfiah, lagu Aneuk Yatim baik dilihat pada lirik maupun melodi menyampaikan sebuah informasi dimana terdapat pesan dan makna terkait dengan perdamaian serta merespon gejolak di Aceh khususnya politik pada masa itu. Melalui lirik dan melodi lagu, Rafly menggambarkan suasana kesedihan terhadap kondisi dan situasi konflik yang cukup lama terjadi di Aceh. Hal ini yang menjadi pembangun suasana dimana kesan kesedihan dapat dirasakan ketika masyarakat Aceh maupun luar Aceh mendengarkan melodi lagu ini. Artinya lagu Aneuk Yatim menjadi simbol dalam menggambarkan peristiwa gejolak politik yang mengakibatkan terjadinya konflik serta juga merepresetasikan fenomena bencana alam seperti tsunami yang dialami oleh masyarakat di Aceh.

Penggunaan instrumen dan harmoni iringan pada melodi lagu Aneuk Yatim memiliki keunikan dimana nada-nada yang dihasilkan dapat membangun suasana, kesan dan pesan terhadap peristiwa yang dialami oleh masyarakat Aceh. Penggunaan instrumen dalam lagu Aneuk Yatim terdiri dari acoustic guitar, keyboard, electric bass, dan drum set. Instrumen tersebut dipakai sebagai pengiring lagu dalam setiap periode atau kalimat lagu dengan menggunakan harmoni iringan dan tangganada konvensional (background harmony). 
Harmoni iringan dan tangganada tersebut telah dibakukan dalam teori musik Barat yang menjadi landasan dalam penciptaan melodi. Harmoni dalam lagu Aneuk Yatim ini, seperti adanya penggunaan tangganada minor asli, dan minor harmonis, serta akor seperti akor I-IV$\mathrm{V}(\mathrm{G}-\mathrm{C}-\mathrm{D})$.

Penggunaan instrumen dan harmoni iringan merupakan salah satu pendukung bentuk penciptaan karya musik melalui ide dan gagasan serta konsep dalam mengolah suatu karya musik. Hal tersebut menjadi sebuah rangkaian pendukung melodi yang dimainkan dalam bentuk instrumen musik untuk menciptakan kesan pada sebuah lagu. Dengan kata lain, penggunaan instrumen dan harmoni iringan dapat juga dikatakan sebagai suksesi linier nada musik sebagai satu kesatuan konsep dalam sebuah karya musik. Secara harfiah, penggunaan instrumen dan pergerakan akor disebut background harmony. Artinya, dapat disimpulkan bahwa background harmony merupakan suatu susunan ritme dalam bentuk scale, akor dan tangganada dalam musik yang tersusun dan dipandang sebagai satu kesatuan dalam mengiringi melodi vokal dalam sebuah lagu. Dengan demikian penggunaan instrumen dan harmoni iringan pada lagu Aneuk Yatim ciptaan Rafly Kande dapat dilihat pada scale, akor dan tangganada yang terdapat pada melodi vokal lagu.

Berdasarkan permasalahan di tersebut, penelitian ini mencoba untuk mengidentifikasi dan menganalisis penggunaan instrumen dan harmoni iringan pada lagu Aneuk Yatim ciptaan Rafly Kande. Proses penciptaan melodi serta kesan pada lagu ditandai dengan adanya pemakaian instrumen dan harmoni konvensional dalam teori dan konsep musik Barat. Tujuan dari penelitian ini yaitu untuk mengetahui dan mendeskripsikan secara terstruktur terkait penggunaan instrumen dan harmoni iringan mulai dari awal sampai akhir lagu Aneuk Yatim ciptaan Rafly Kande, yang nantinya bisa menjadi rujukan dan referensi bagi peneliti dalam menganalisis karya musik Pop di Indonesia pada umumnya, baik karya musik pop daerah maupun nasional.

Secara teoritis, penggunaan teori musik Barat dijadikan sebagai konsep pemikiran dalam menganalisis penggunaan instrumen dan harmoni iringan pada lagu Aneuk Yatim ciptaan Rafly Kande. Menurut Prier (Prier, 1996) mengatakan bahwa ilmu analisis musik adalah 'memotong' dan memperhatikan detil sambil melupakan keseluruhan dari sebuah karya musik. Keseluruhan berarti: memandang awal dan akhir dari sebuah lagu serta beberapa perhentian sementara di tengahnya; gelombang-gelombang naik turun dan tempat puncaknya; dengan kata lain: dari segi struktur. Artinya, penggunaan instrumen serta harmoni iringan merupakan bagian dari struktur musik dalam penciptaan sebuah karya seni musik, seperti lagu Aneuk Yatim. Dengan demikian, peneliti mencoba mengidentifikasi dan menganalisis bagaimana penggunaan musik iringan yang meliputi instrumentasi dan harmoni iringan pada lagu Aneuk Yatim yang diciptakan oleh Rafly Kande sebagai rumusan masalah dalam penelitian ini. 
Metode

Penelitian ini menggunakan pendekatan kualitatif, dengan didukung oleh metode analisis deskriptif. Selanjutnya, pendekatan yang dilakukan untuk mempermudah pencarian data, dilakukan dengan pendekatan etik dan emik agar tercapainya kelancaran dalam proses pencarian sampai dengan pengelolaan data untuk mengindentifikasi penggunaan instrumen musik dan harmoni iringan pada lagu Aneuk Yatim. Selanjutnya, dilakukan interaksi langsung dalam pengumpulan data terkait subjek dan objek. Menurut Creswell (Rulam, 2014) mengatakan bahwa metode kualitatif adalah multimetode dalam fokus, termasuk pendekatan interpretasi dan naralistik terhadap pokok permasalahan. Metode kualitatif digunakan sebagai instrumen kunci (researcher as key instrument) yang dilakukan dengan cara pengumpulan data terkait subjek dan objek melalui dokumentasi, observasi, serta wawancara dengan partisipan. Artinya, metode kualitatif menjadi cara atau tahap dalam membantu peneliti mulai dari pengumpulan data, pengolahan, analisis sampai dengan hasil yang didapatkan dalam membedah objek material penelitian ini yaitu lagu Aneuk Yatim, dengan objek formal yaitu penggunaan instrumen musik dan harmoni iringan lagu. Hal ini juga ditegaskan oleh Moleong (Moleong, 2021), yang mengatakan bahwa penggunaan konsep dalam penelitian kualitatif, pertama, menyesuaikan metode kualitatif lebih mudah apabila berhadapan dengan kenyataan jamak, kedua, metode ini juga menyajikan secara langsung hubungan antara peneliti dan responden, serta ketiga, metode ini lebih peka dan lebih menyesuaikan diri dengan banyak penajaman pengaruh terhadap pola-pola nilai yang dihadapi.

Sebagai bahan perbandingan dalam menelaah keaslian dan originalitas serta menghindari adanya plagiasi, untuk mencari persamaan dan perbedaan dengan penelitian lain, maka perlu dilakukan kajian pustaka. Salah satu penelitian terkait adalah penelitian dalam jurnal Abdul Rozak, dkk. yang berjudul "Analisis Melodi pada Lagu Aneuk Yatim Ciptaan Rafly Kande" (Abdul Rozak et al., 2020). Penelitian ini mendeskripsikan dan menganalisis susunan melodi pada lagu Aneuk Yatim ciptaan Rafly Kande dengan menggunakan pendekatan struktur dan bentuk musik. Persamaan penelitian ini dengan penelitian yang dilakukan adalah penggunaan objek material, dimana sama-sama mengkaji isian musik seperti melodi pada lagu Aneuk Yatim. Namun, perbedaan dalam penelitian ini lebih memfokuskan pada analisis penggunaan instrumen dan harmoni iringan pada lagu Aneuk Yatim yang diciptakan oleh Rafly Kande. 
Hasil

\section{Analisis Musik Iringan Lagu Aneuk Yatim Ciptaan Rafly Kande}

Analisis dalam penelitian ini bertolak pada bentuk melodi pokok yang dapat dilihat dalam notasi berikut.

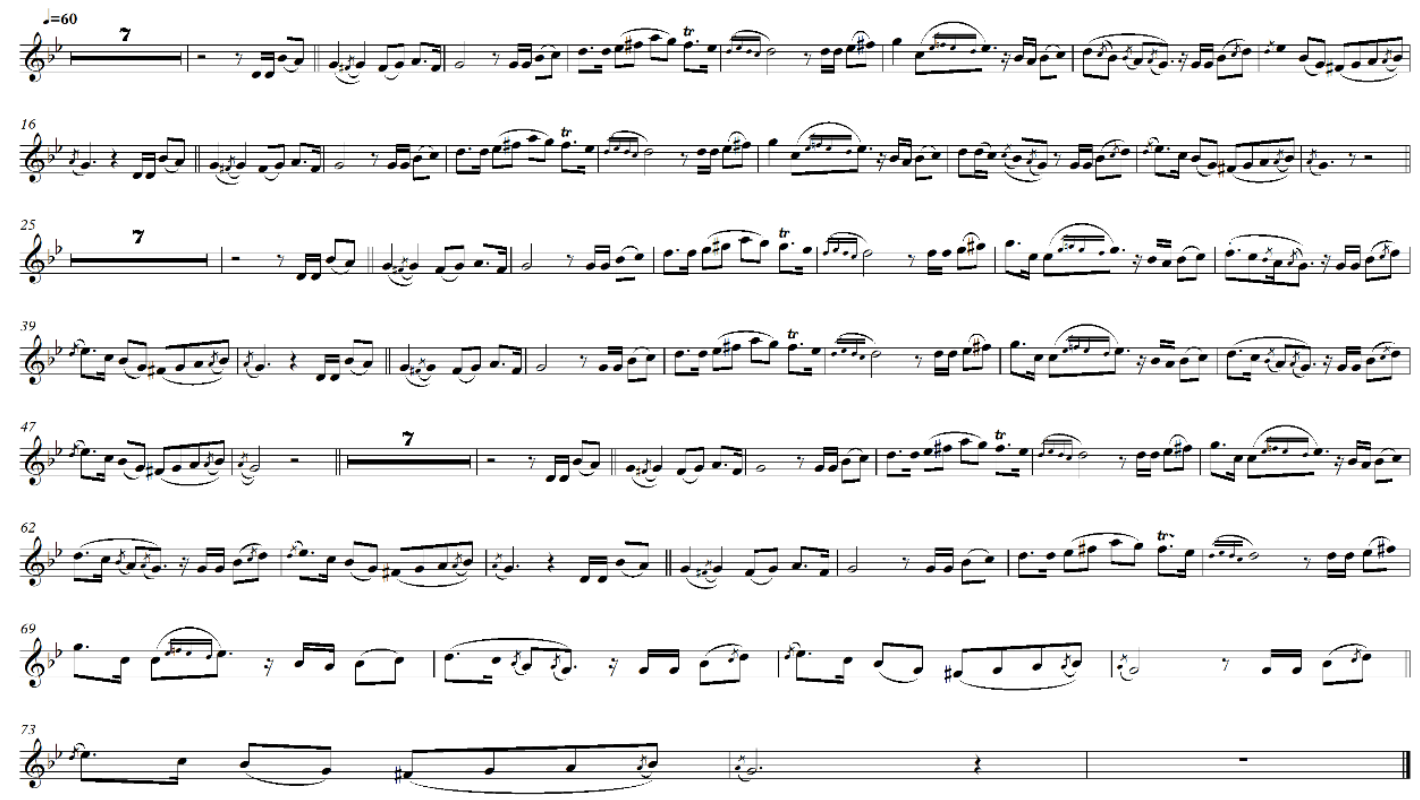

Notasi 1. Melodi Pokok Lagu Aneuk Yatim

Adapun analisis penggunaan instrumen musik dan harmoni iringan yang terdapat pada lagu Aneuk Yatim dapat dideskripsikan sebagai berikut:

a. Introduction (birama 1-8)

Pada bagian pembuka (Introduction) terdiri dari delapan buah birama, dimana bagian tersebut dimainkan oleh instrumen Keyboard. Masing-masing bagian ini terbagi dari dua periode/ kalimat (A dan B) yang disebut dengan kalimat antecedents dan consequents, dua kalimat tersebut biasanya disebut dengan kalimat tanya dan kalimat jawab.

Periode/ kalimat A pada birama 1-4, terdiri atas 2 motif yang meliputi motif a dan motif b, dimana masing-masing motif menggunakan scale yang berbeda-beda. Dimana pemakaian scale pada motif a menggunakan tangganada G Minor Harmonis sedangkan pemakaian scale pada motif $b$ menggunakan tangganada $G$ Minor Asli. Pada periode/kalimat $A$ ini menggunakan musik iringan yang terdiri dari instrumen Guitar Accoustic, Electric Bass, Keyboard, dan instrumen perkusi Drum Set. Pergerakan akor yang dipakai pada kedua motif dalam periode/kalimat $A$ ini adalah (i-v-i-i-iv-i). Musik pengiring dalam periode/kalimat $A$, dapat dilihat pada notasi berikut. 


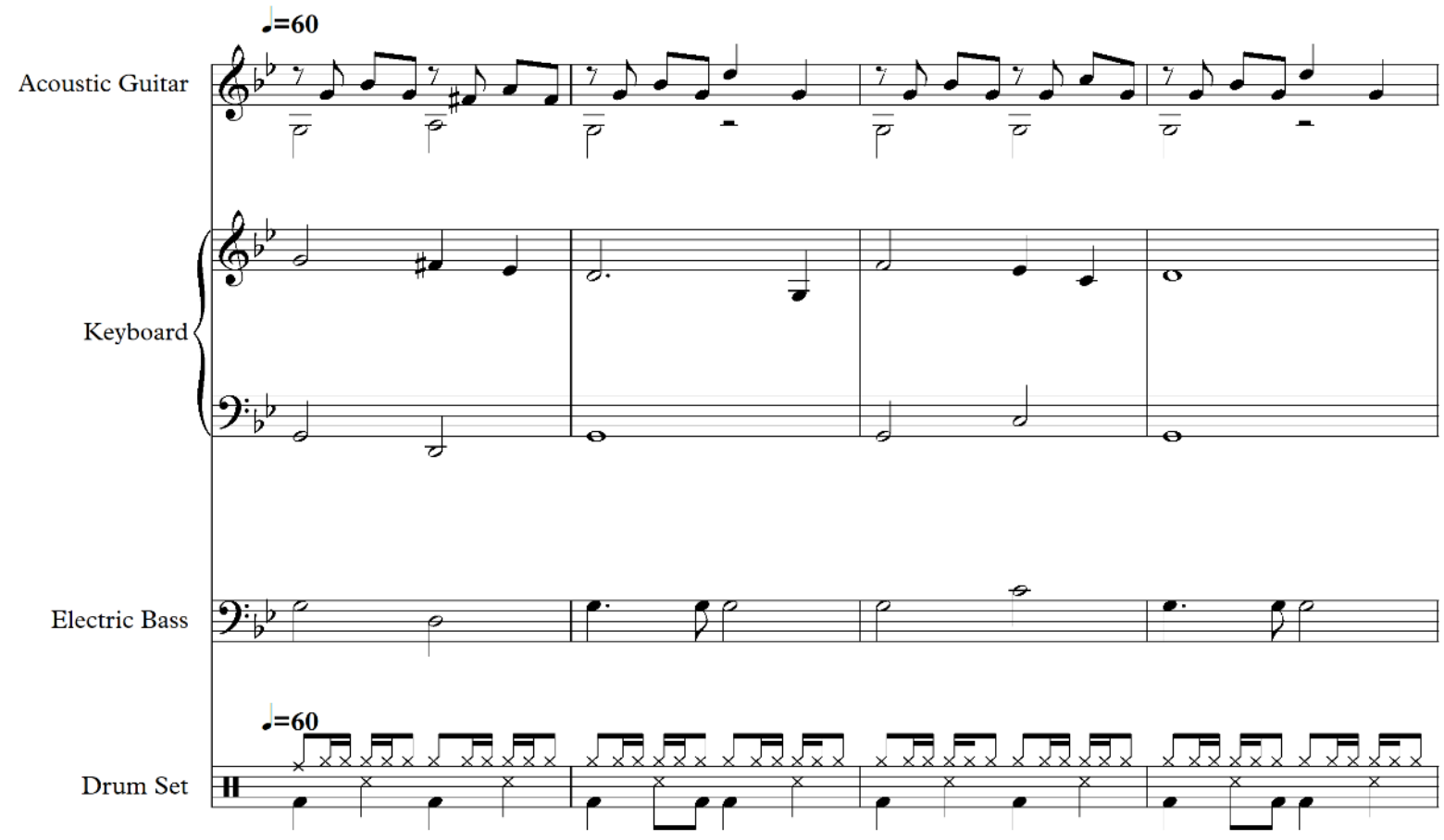

Notasi 2. Musik Pengiring Periode/ Kalimat A Introduction

Periode/ kalimat B pada birama 5-8 juga terdiri atas 2 (dua) motif, dimana disebutkan sebagai motif a dan motif $b$. Masing-masing motif baik a dan $b$ menggunakan scale yang berbeda-beda. Perbedaaan scale tersebut terlihat pada penggunaan tangganada yaitu pada motif a mengunakan tangganada $G$ Minor Asli sedangkan motif $b$ memakai tangganada $G$ Minor Harmonis. Pada periode/kalimat B ini menggunakan musik iringan yang terdiri dari instrumen Guitar Accoustic, Electric Bass, Keyboard, dan Drum Set. Pergerakan akor yang dipakai pada kedua motif dalam periode/kalimat B ini adalah (iv-i-iii-v-i), dapat dilihat pada notasi berikut.

Acoustic Guitar

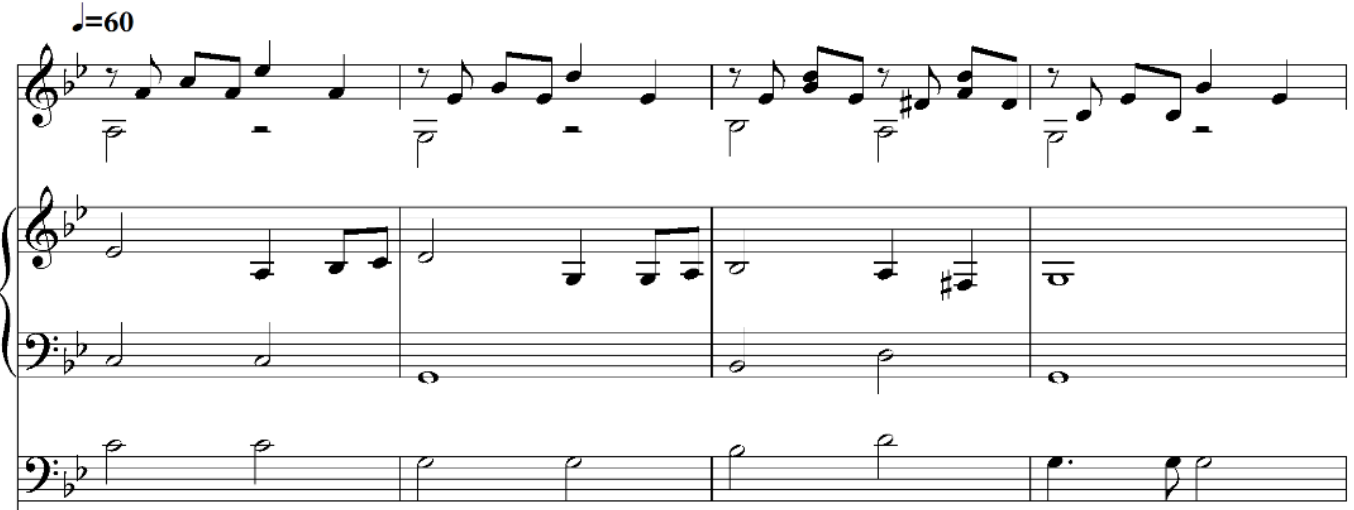

Electric Bass

Drum Set

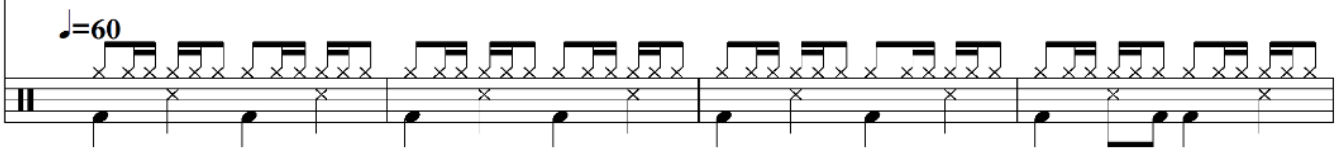

Notasi 3. Musik Pengiring Periode/ Kalimat B Introduction 
b. Bagian I (birama 8-24)

Pada bagian I terdiri dari 16 birama dan 2 periode/kalimat $\left(A, A^{\prime}\right)$ yang terdapat pada instrumen vokal. Periode/kalimat A pada birama 8-16, terbagi menjadi 4 (empat) motif yaitu motif $a, b, c$, dan $\mathrm{d}$. Masing-masing motif memiliki perbedaan dalam pengunaan tangganada. $\mathrm{Hal}$ ini dapat dilihat pada motif a dan $\mathrm{b}$ menggunakan scale tangganada $\mathrm{G}$ Minor Harmonis, sedangkan pada motif c memakai tangganada G Minor Asli dan G Minor Harmonis; serta pada motif d dengan scale tangganada G Minor Harmonis. Artinya, dari keseluruhan bagian pada periode A merupakan bagian pengulangan kalimat di bagian selanjutnya, namun pada akhir frase adanya perbedaan figures antara dua kalimat tersebut.

Pada periode/kalimat $A$ ini menggunakan musik iringan yang terdiri dari instrumen Guitar Accoustic, Electric Bass, dan instrumen perkusi Drum Set. Pergerakan akor yang dipakai pada kedua motif dalam periode/kalimat $A$ ini adalah (i-v-i-i-iv-i- iv-i-iii-v-i). Musik pengiring dalam periode/kalimat $A$ ini dapat dilihat pada notasi berikut.

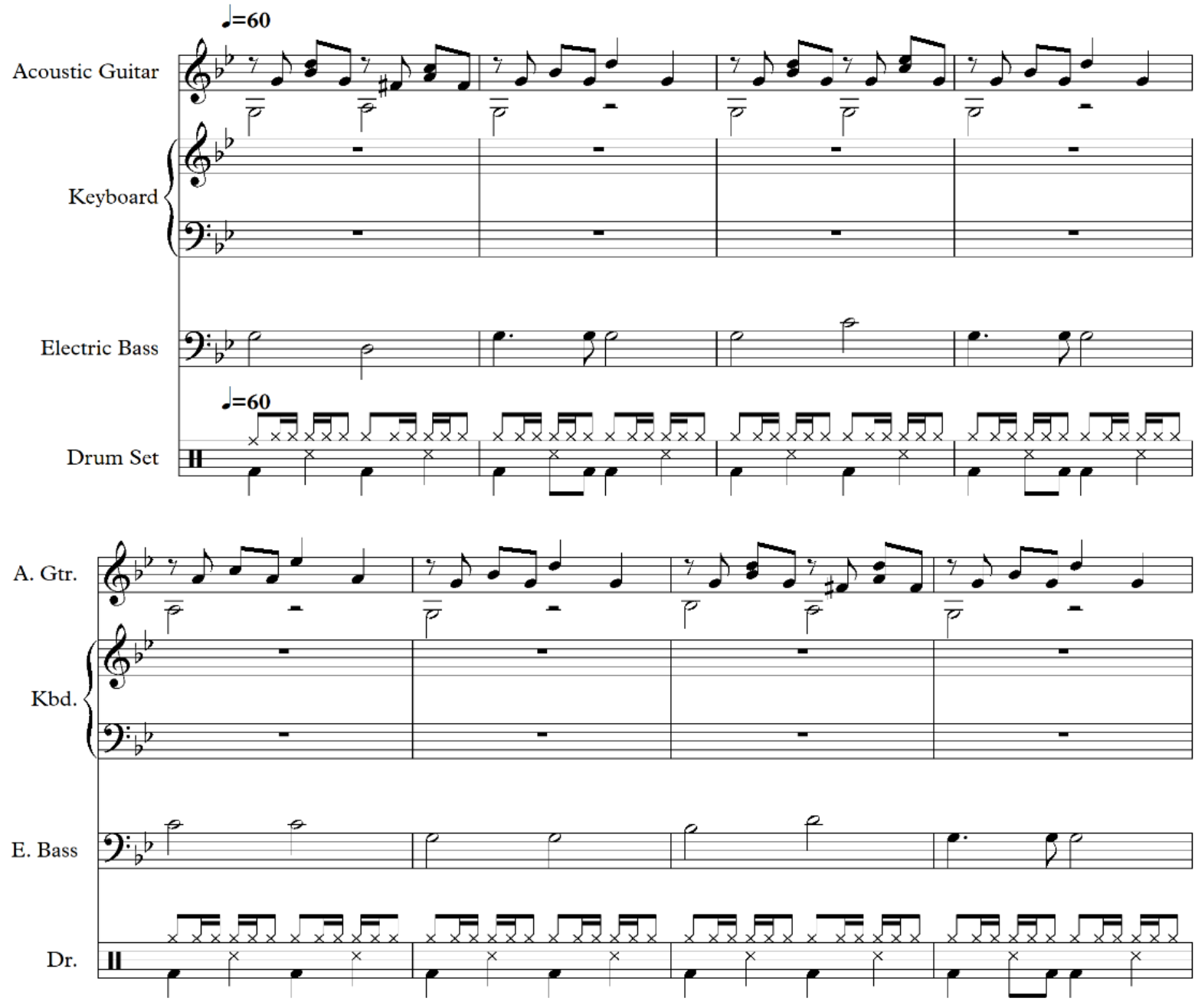

Notasi 4. Musik Pengiring Periode/ Kalimat A Bagian I

Dilihat dari kesamaan motif a dan motif b dengan kalimat sebelumnya, pemakaian scale adalah G Minor Harmonis. Sedangkan pada motif c memakai scale G Minor Asli dan Harmonis; motif d memakai scale $G$ Minor Harmonis. Namun terdapat motif yang berbeda pada pengulangan pada periode $B$, yaitu perbedaan figures pada akhir frase pada motif $c$, 
notasi dengan nilai $1 / 8$ ke notasi $1 / 16$ yang terletak pada ketukan lemah (teknik pengembangan yang dipakai adalah diminished). Hal ini menunjukkan bahwa adanya pengembangan melodi yang dipakai pada figures akhir di motif c.

Pada periode/kalimat $A$ ini menggunakan musik iringan yang terdiri dari instrumen Guitar Accoustic, Electric Bass, Keyboard dan instrumen Drum Set. Pergerakan akor yang dipakai pada kedua motif dalam periode/kalimat B ini adalah (i-v-i-i-iv-i- iv-i-iii-v-i). Musik pengiring dalam periode/kalimat $A$ ini dapat dilihat pada notasi berikut.

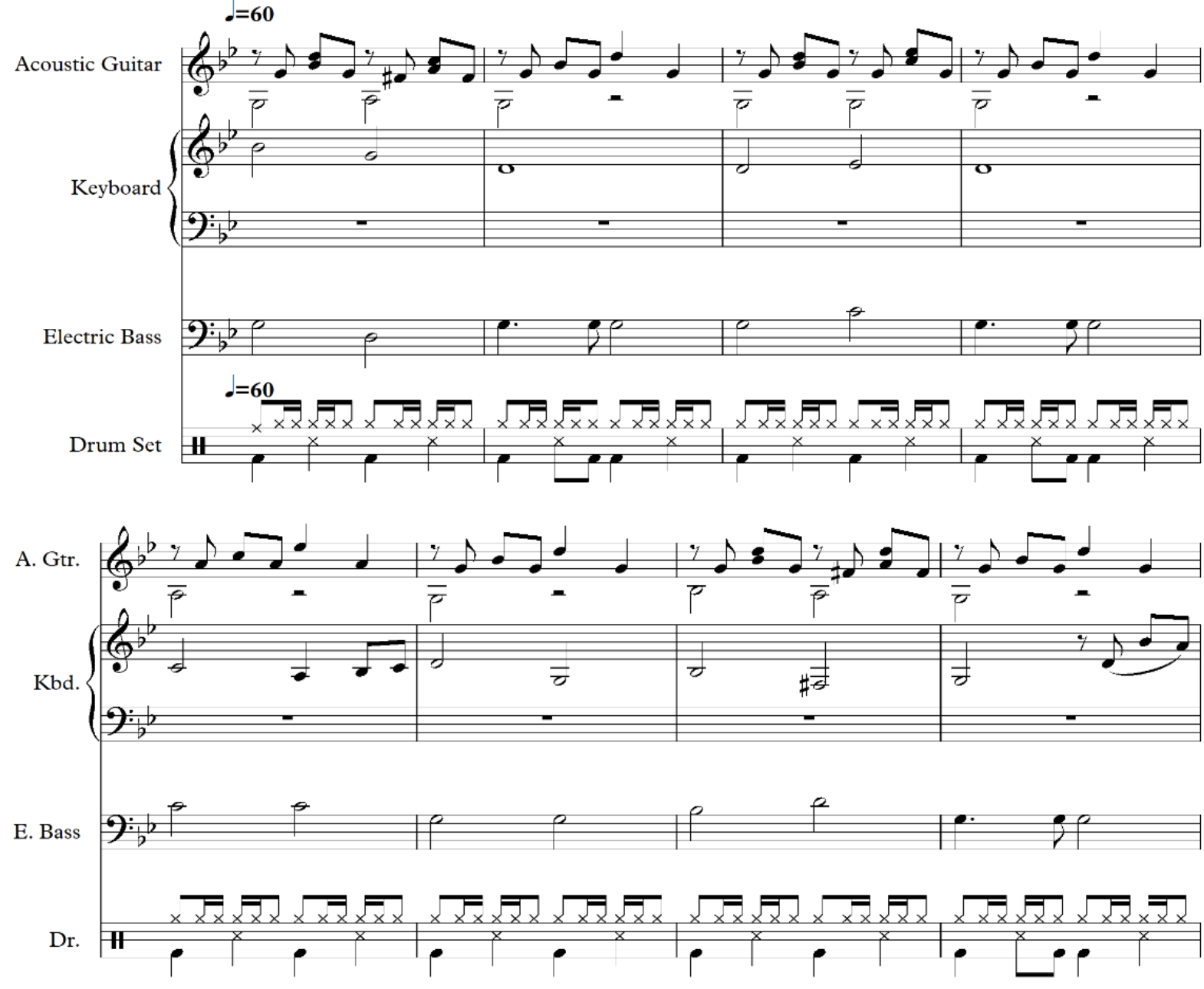

Notasi 5. Musik Pengiring Periode/ Kalimat B Bagian I

c. Interlude (birama 25-32)

Interlude terdiri dari 8 birama, Motif-motif yang dipakai merupakan pengulangan dan pengembangan melodi dengan teknik sekuen. Pada pengulangan motif ini adanya penggunaan dan pemakaian instrumen yang berbeda, yaitu instrumen Keyboard. Pada bagian Interlude ini menggunakan musik iringan yang terdiri dari instrumen Guitar Accoustic, Electric Bass dan instrumen Drum Set. Pergerakan akor yang dipakai pada kedua motif dalam periode/kalimat B ini adalah (i-v-i-i-iv-i- iv-i-iii-v-i). Musik pengiring pada bagian ini dapat dilihat pada notasi berikut. 

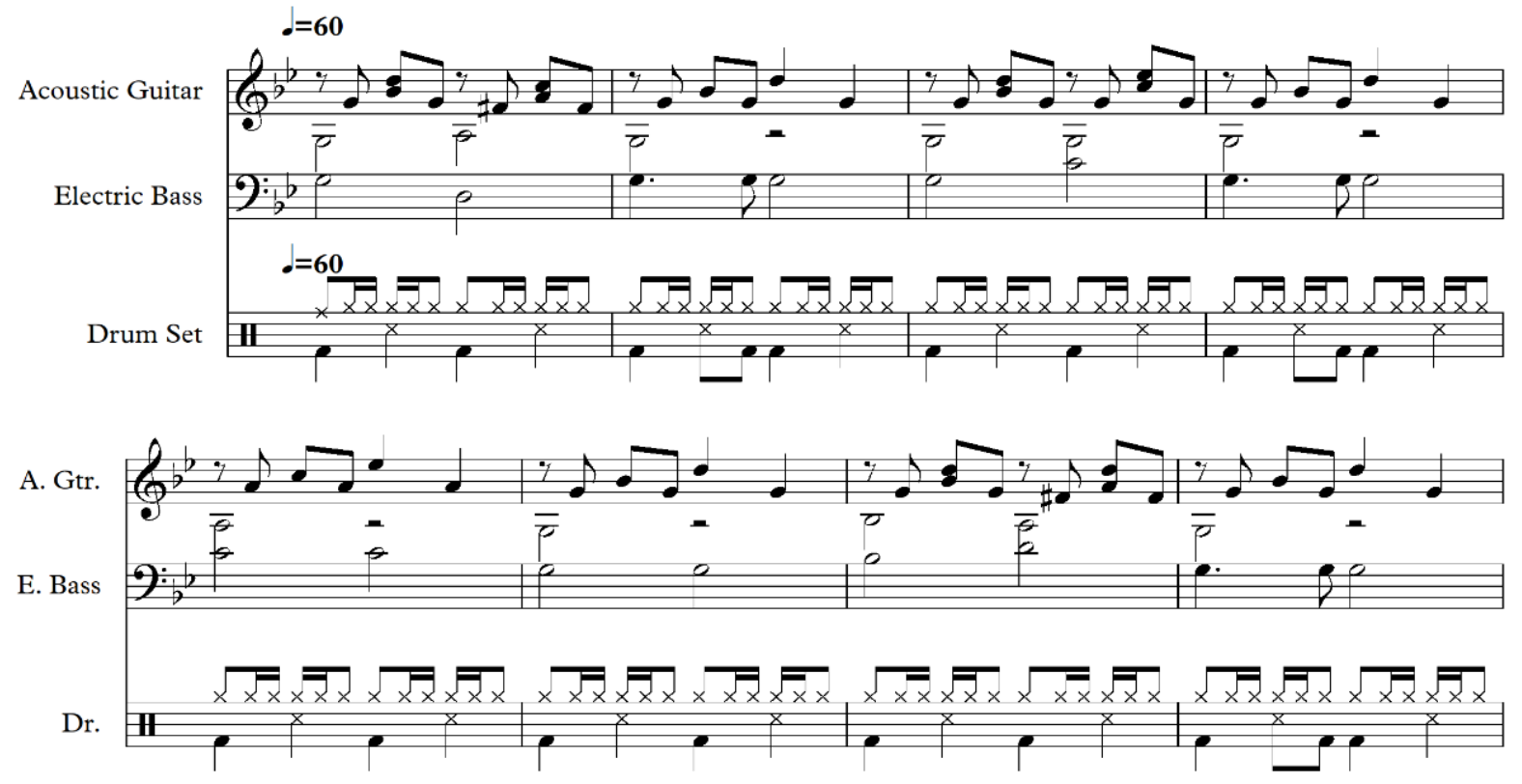

Notasi 6. Musik Pengiring Interlude/ Transisi I

d. Bagian II (birama 32-48)

Bagian II terdiri atas 16 birama, serta terdapat 2 periode/kalimat (A, $\left.A^{\prime}\right)$. Periode/kalimat $A$ dan $A^{\prime}$ adalah bagian yang diulang dengan pemakaian pengembangan pola ritme pada figures di bagian akhir yang dapat diihat pada beberapa motif melodi. Artinya, periode/kalimat tersebut merupakan pengulangan secara keseluruhan motif dengan pengembangan pada akhir kalimat.

Pada motif a dan b memakai scale G Minor Harmonis, sedangkan pada motif c memakai scale $\mathrm{G}$ Minor Asli dan Harmonis serta motif d memakai scale $\mathrm{G}$ Minor Harmonis. pada periode/kalimat $A$ ini menggunakan musik iringan yang terdiri dari instrumen Guitar Accoustic, Electric Bass, Keyboard dan Drum Set. Pergerakan akor yang dipakai pada kedua motif dalam periode/kalimat $B$ ini adalah (i-v-i-i-iv-i- iv-i-iii-v-i). Musik pengiring dalam periode/kalimat A ini dapat dilihat pada notasi berikut. 


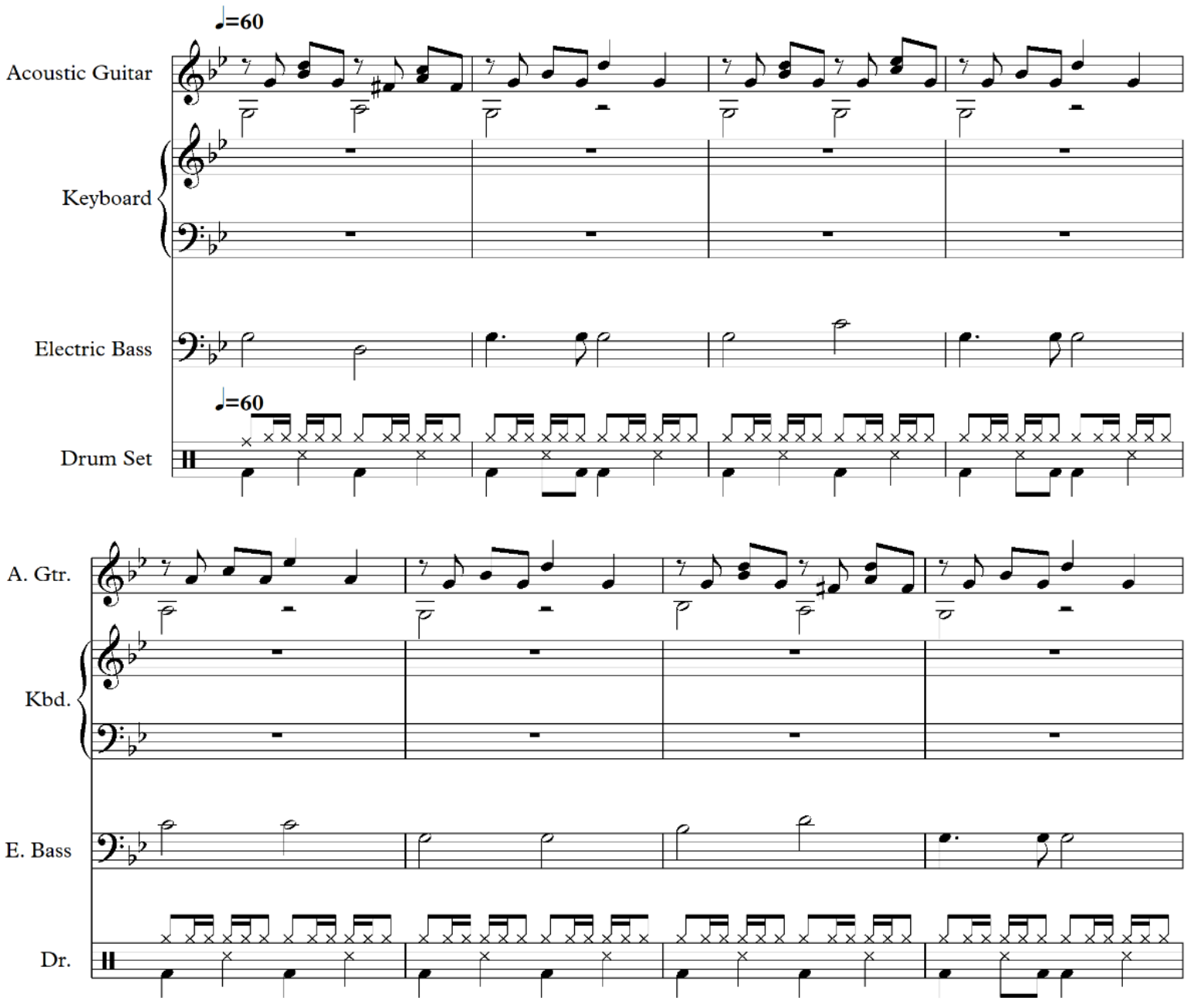

Notasi 7. Musik Pengiring Periode/ Kalimat A Bagian II

Periode/ kalimat B terletak pada birama 40-48, dengan 4 buah motif yaitu motif a, b, c, dan $\mathrm{d}$, dimana disetiap motif memiliki perbedaan dalam pemakaian scale. Penggunaan scale tersebut dapat diidentifikasi dimana motif a dan motif $b$ menggunakan scale $G$ Minor Harmonis, sedangkan motif c memakai scale G Minor Asli Harmonis dan motif d dengan scale G Minor Harmonis.

Pada periode/kalimat B ini menggunakan musik iringan yang terdiri dari instrumen Guitar Accoustic, Electric Bass, Keyboard dan Drum Set. Pergerakan akor yang dipakai pada kedua motif dalam periode/kalimat B ini adalah (i-v-i-i-iv-i- iv-i-iii-v-i). Musik pengiring dalam periode/kalimat B ini dapat dilihat pada notasi berikut. 


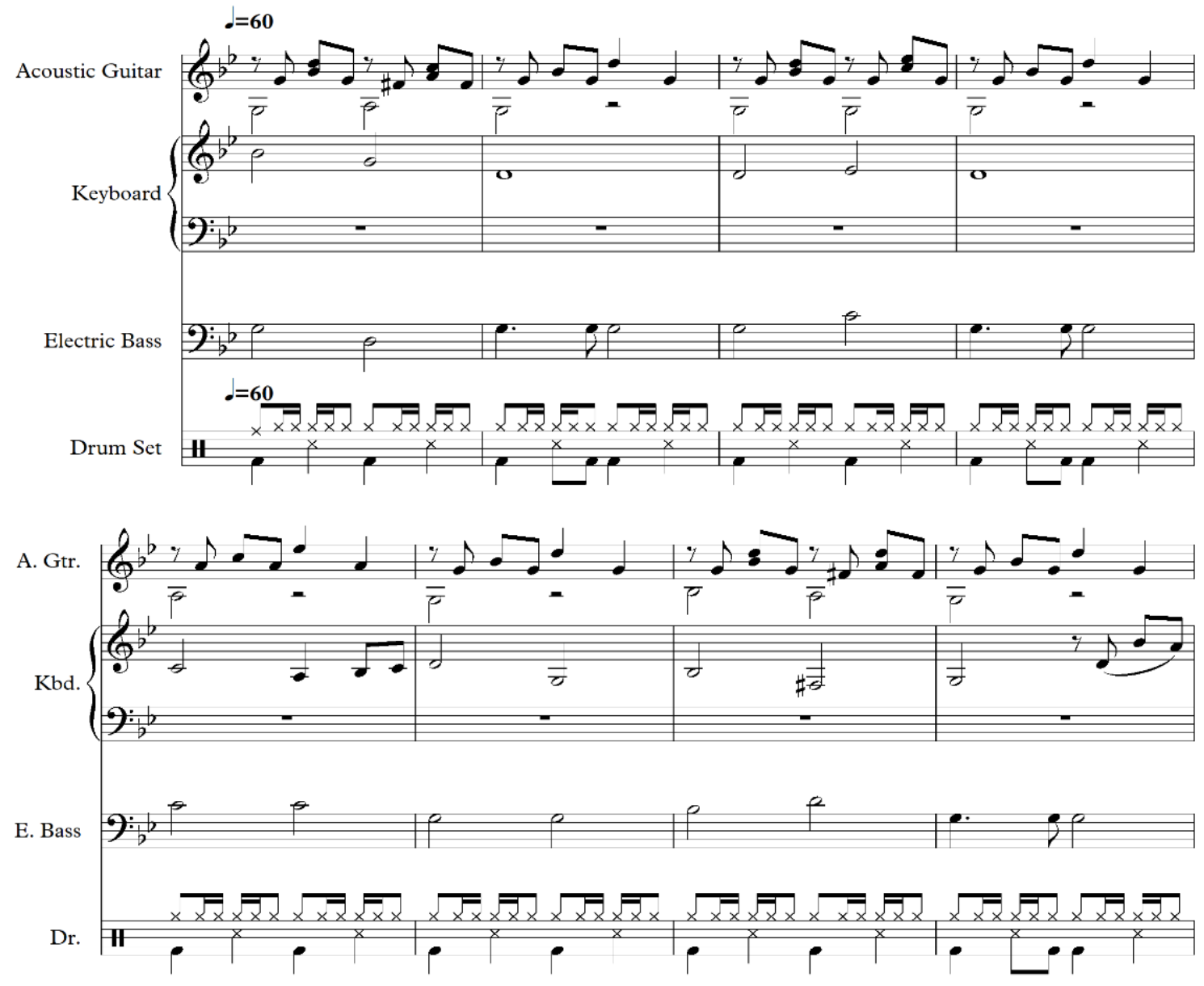

Notasi 8. Musik Pengiring Periode/ Kalimat B Bagian II

e. Interlude II (birama 48-56)

Interlude II terdiri dari sembilan birama. Motif a dan b terdapat kesamaan dengan periode sebelumnya, seperti motif yang sama dan scale masih memakai G Minor Harmonis. Pada motif c mengalami pengembangan pada scale, yaitu memakai Tangganada $G$ Minor Asli, sedangkan motif d menggunakan scale G Minor Harmonis. Dengan demikian, pada bagian Interlude II sebagian besar mengalami perubahan dan pengembangan melodi, yaitu dalam pemakaian scale.

Pada bagian Interlude II ini menggunakan musik iringan yang terdiri dari instrumen Guitar Accoustic, Electric Bass dan instrumen Drum Set. Pergerakan akor yang dipakai pada kedua motif dalam periode/kalimat B ini adalah (i-v-i-i-iv-i- iv-i-iii-v-i). Musik pengiring pada bagian ini dapat dilihat pada notasi berikut. 


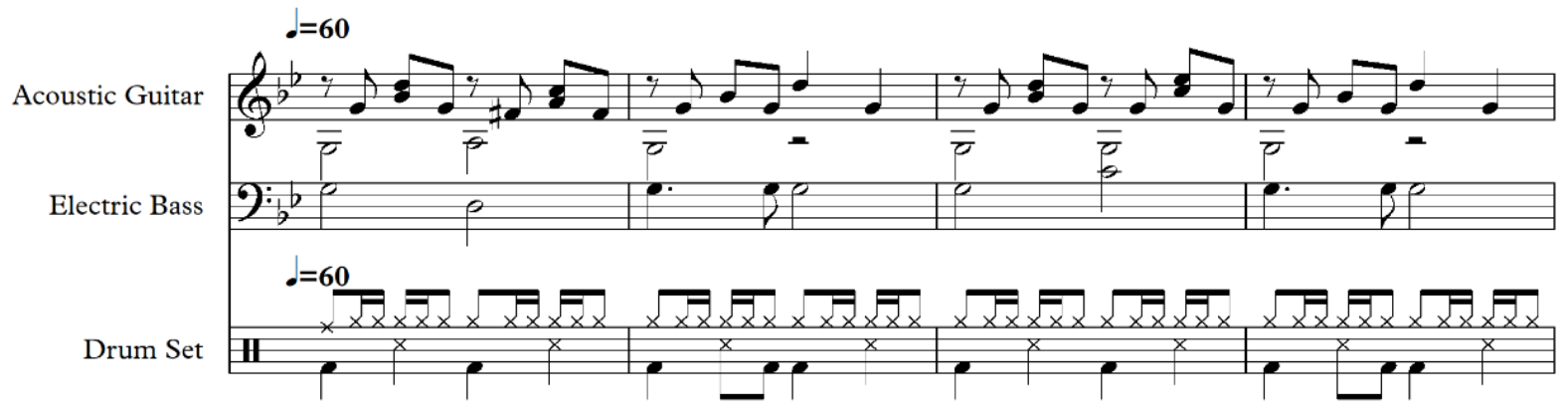

A. Gtr.

E. Bass

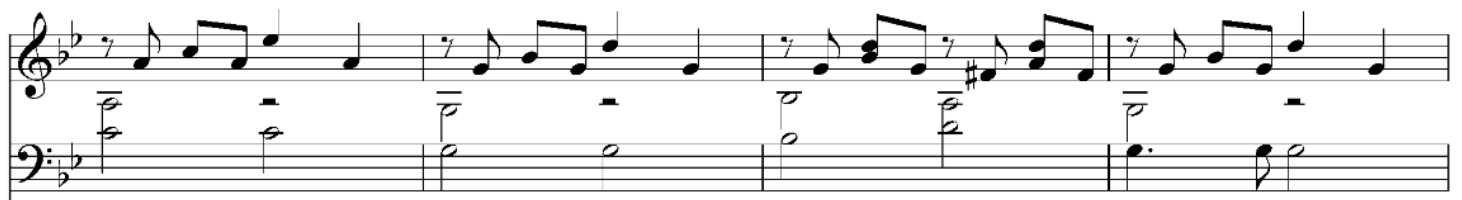

Dr.

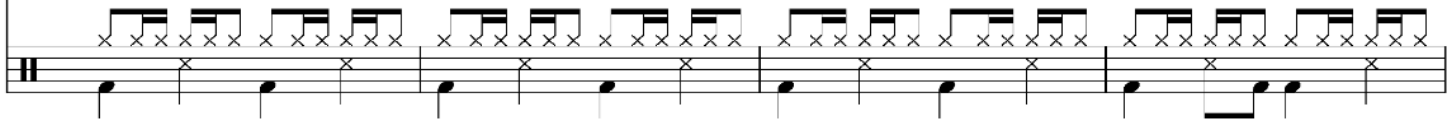

Notasi 9. Musik Pengiring Interlude II/Transisi

f. Bagian III (birama 56-72)

Bagian III terdiri dari 16 (enam belas) birama, terbagi menjadi 4 (empat) motif yang meliputi motif $a, b, c$, dan d. Pada motif a dan b memakai scale G Minor Harmonis. Berbeda dengan motif $\mathrm{c}$ dan $\mathrm{d}$, dimana motif $\mathrm{c}$ menggunakan $\mathrm{G}$ Minor Asli dan Harmonis sedangkan motif d memakai scale G Minor Harmonis. Artinya, bagian III pada lagu Aneuk Yatim memiliki kesamaan dengan bagian sebelumnya yaitu dalam pemakaian scale Minor Asli dan Minor Harmonis.

Pada periode/ kalimat $A$ ini menggunakan musik iringan yang terdiri dari instrumen Guitar Accoustic, Electric Bass, Keyboard dan Drum Set. Pergerakan akor yang dipakai pada kedua motif dalam periode/kalimat B ini adalah (i-v-i-i-iv-i- iv-i-iii-v-i). Musik pengiring dalam periode/kalimat $\mathrm{A}$ ini dapat dilihat pada notasi berikut. 


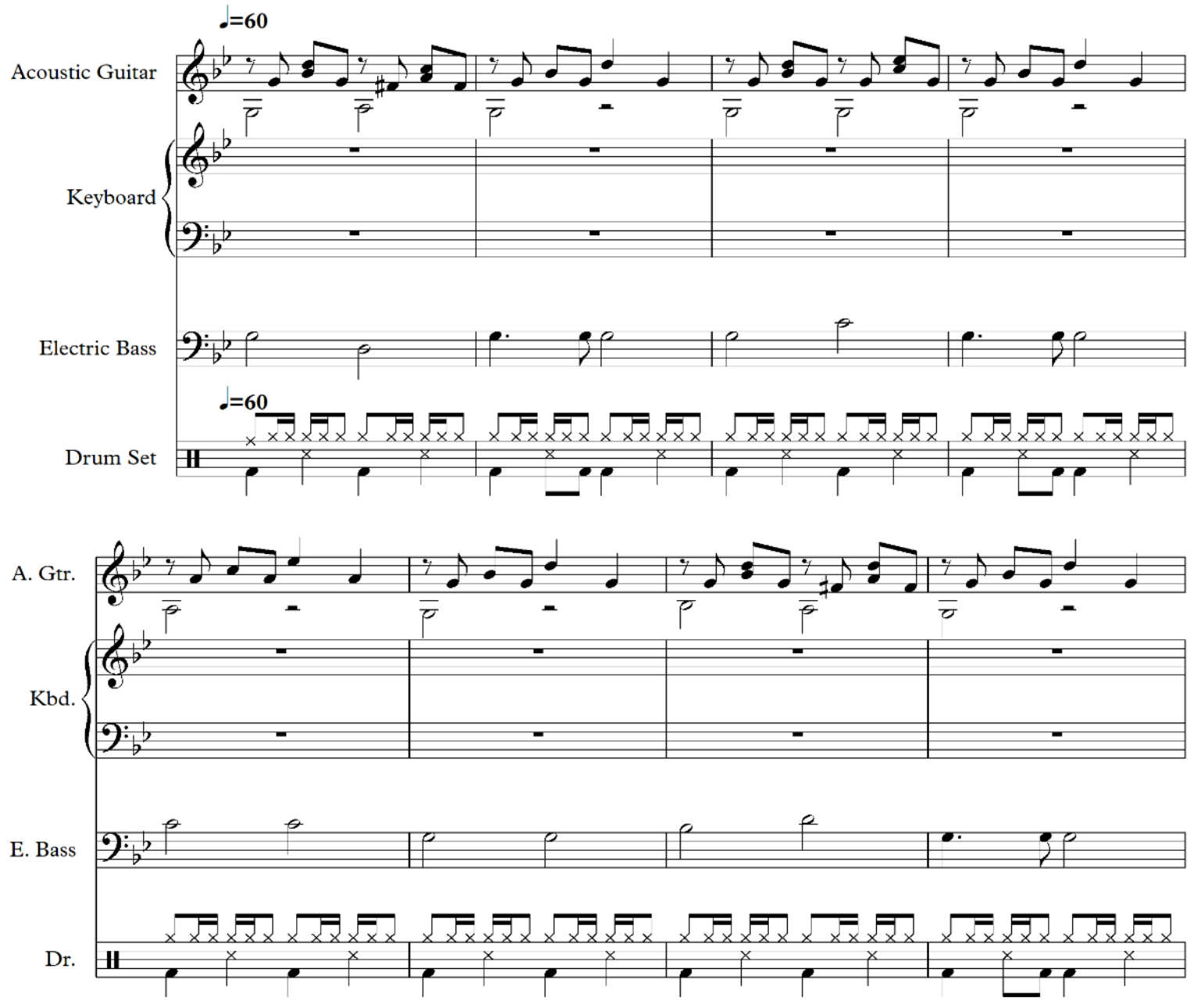

Notasi 10. Musik Pengiring Periode/ Kalimat A Bagian III

Periode/kalimat B pada birama 64-72 juga terdapat 4 motif yang dibagi menjadi motif $a, b, c$ dan $d$. Motif a dan b menggunakan scale $G$ Minor Harmonis. Berbeda dengan motif $c$ dan d, dimana pada motif c menggunakan scale $\mathrm{G}$ Minor Asli Harmonis sedangkan motif d memakai scale G Minor Harmonis. Artinya, pemakaian scale Minor Asli dan Minor Harmonis di bagian periode $B$ terdapat kesamaan, dimana kesamaan tersebut merupakan kalimat pengulangan dari kalimat sebelumnya.

Pada periode/kalimat B ini menggunakan musik iringan yang terdiri dari instrumen Guitar Accoustic, Electric Bass, Keyboard dan Drum Set. Pergerakan akor yang dipakai pada kedua motif dalam periode/kalimat $B$ ini adalah (i-v-i-i-iv-i- iv-i-iii-v-i). Musik pengiring dalam periode/kalimat $B$ ini dapat dilihat pada notasi berikut. 

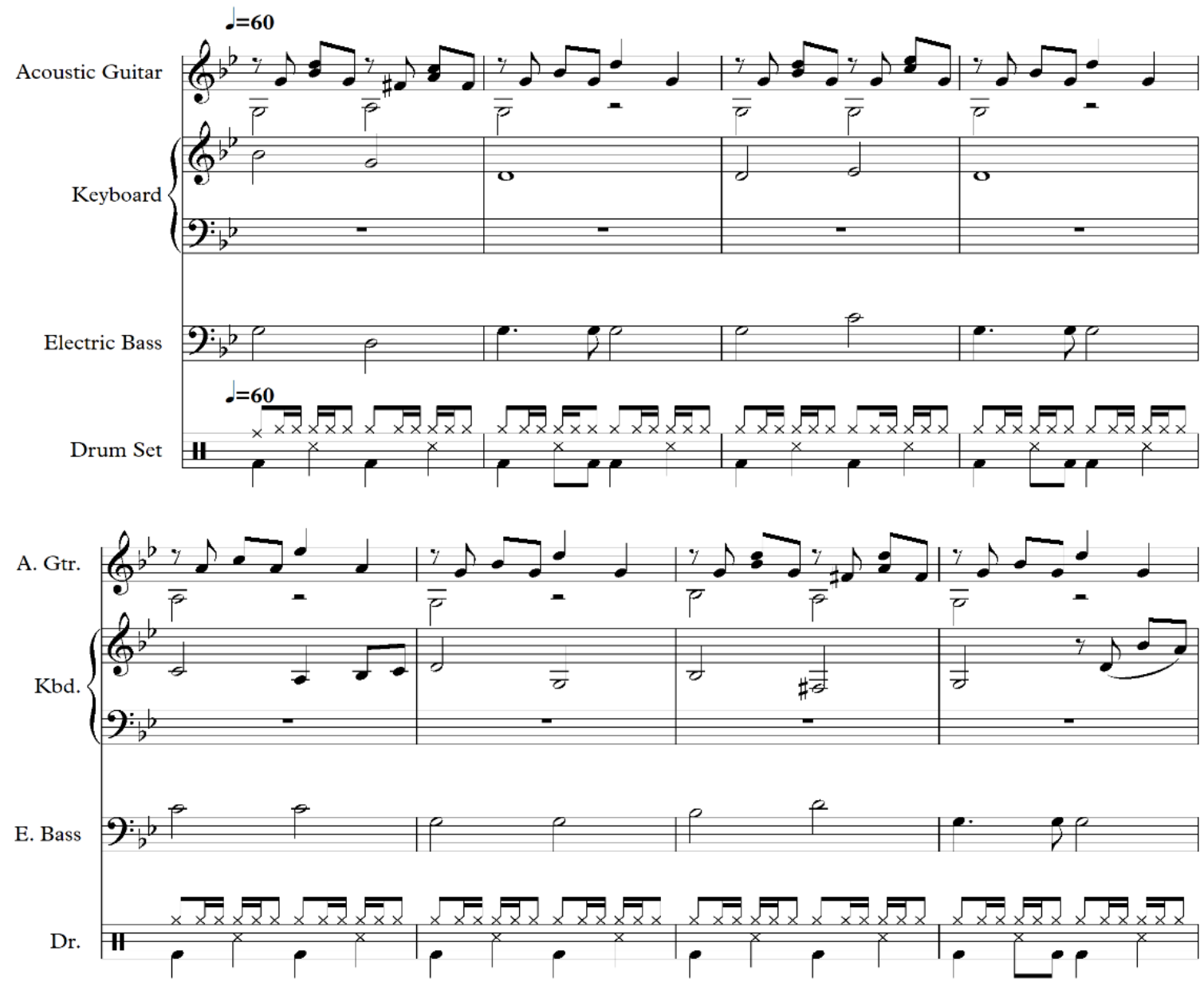

Notasi 11. Musik Pengiring Periode/ Kalimat B Bagian III

\section{g. Coda (birama 48-50)}

Pada bagian akhir atau Coda memiliki empat birama, dimana motif yang digunakan merupakan pengulangan motif yang sama dengan bagian sebelumnya. Pada Coda ini menggunakan musik iringan yang terdiri dari instrumen Guitar Accoustic, Electric Bass, Keyboard dan Drum Set. Pergerakan akor yang dipakai pada kedua motif dalam periode/kalimat B ini adalah (iii-v-i-i). Musik pengiring dalam periode/kalimat B ini dapat dilihat pada notasi berikut. 


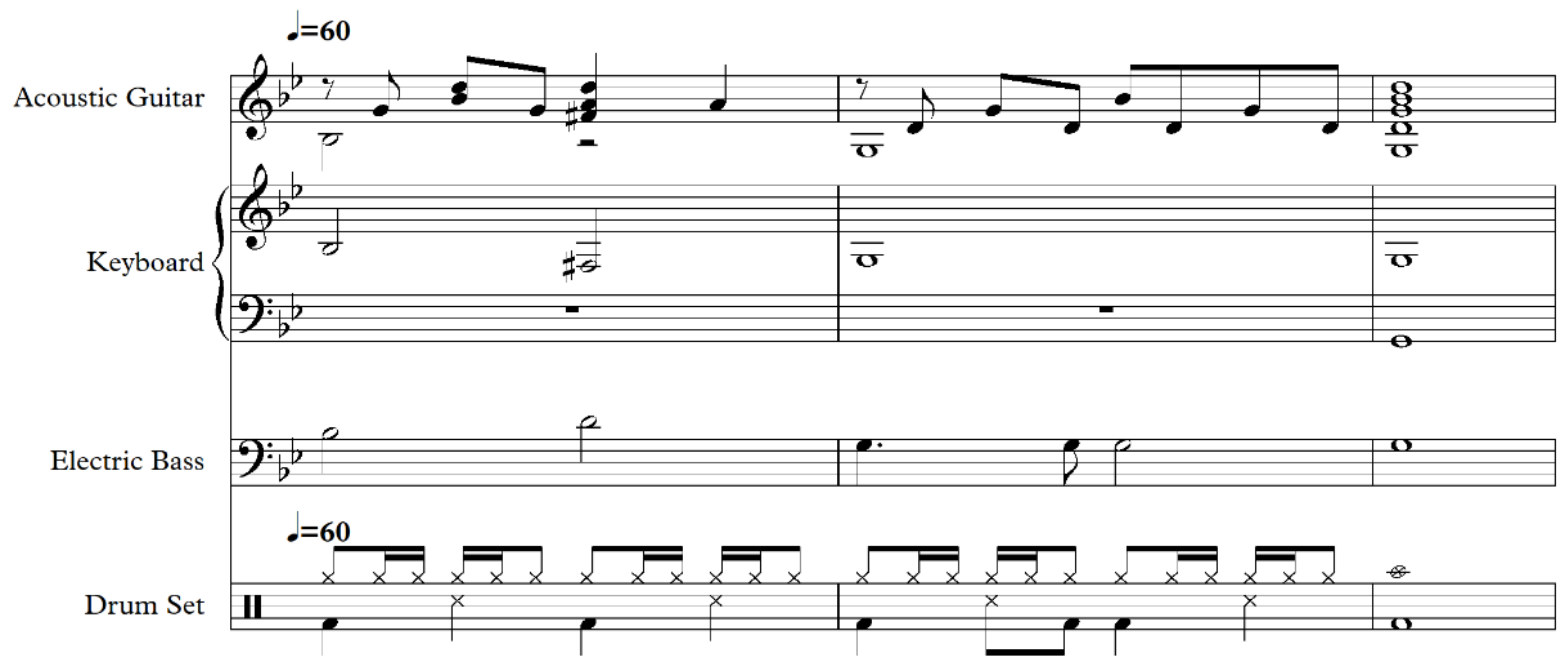

Notasi 12. Musik Pengiring Coda

Dengan demikian, melodi lagu yang terdapat pada lagu Aneuk Yatim ini sebagian besar merupakan pengulangan motif yang terdapat pada melodi pokok. Pengulangan yang dilakukan terdiri dari motif-motif pada masing-masing bagian. Pada beberapa bagian, motifmotif tersebut mengalami pengembangan figures melodi di bagian akhir kalimat, seperti adanya pemakaian teknik pengembangan melodi sekuen, pemakaian instrumen serta perubahan scale (harmoni). Penggunaan instrumen iringan pada lagu Aneuk Yatim yaitu instrumen Guitar Accoustic, Electric Bass, Keyboard dan Drum Set memainkan semua bagian mulai dari Interlude, bagian I, bagian II, Bagian III, dan coda. Dengan demikian, instrumen tersebut yang memainkan harmoni berperan penting dalam membantu mengikuti melodi vokal bagian per bagian. Maka dari itu, instrumen iringan dengan pemakaian harmoni serta melodi pada lagu Aneuk Yatim ini menjadi satu kesatuan dalam mendukung kesan dan pesan yang disampaikan pada sebuah karya musik.

\section{Pembahasan}

\section{Minor Asli dalam Lagu Aneuk Yatim}

Musik merupakan karya seni yang berupa bunyi dalam bentuk lagu atau komposisi yang mengungkapkan pikiran dan perasaan penciptanya melalui unsur-unsur musik yaitu irama, melodi, harmoni, bentuk dan struktur lagu (Jamalus, 1988). Aneuk Yatim merupakan karya musik lagu ciptaan Rafly Kande struktur lagu yang terdiri dari dua kalimat lagu/periode. Dua kalimat tersebut disusun oleh motif-motif yang pada masing-masing motif tersebut diulang pada kalimat lagu/periode selanjutnya dengan adanya perubahan struktur melodi pada bagian figures (kalimat penutup). Figur atau figures merupakan suatu unit konstruksi terkecil dalam musik yang setidak-tidaknya berisi satu karakteristik irama dan satu karakteristik interval (Leon Stein, 1979).

Lagu Aneuk Yatim memiliki penggunaan instrumen dan harmoni iringan yang khas dalam mendukung melodi vokal. Penggunaan instrumen dalam lagu Aneuk Yatim selain vokal, terdiri dari acoustic guitar, keyboard, electric bass, dan drum set. Masing-masing instrumen tersebut mempunyai peran tersendiri dalam iringan lagu ini. Misalnya, acoustic guitar, keyboard, dan electric bass merupakan instrumen melodis dan instrumen harmonis 
yang digunakan sebagai instrumen dalam memainkan melodi pada interlude, serta instrumen harmonis yang memainkan akor sebagai iringan pada melodi pokok. Sementaraitu, harmoni iringan dan tangganada pada lagu Aneuk Yatim ini, seperti adanya penggunaan tangganada minor asli, dan minor harmonis, serta akor yang dipakai seperti akor I-IV-V (G-C-D).

Tangganada yang digunakan di lagu Aneuk Yatim ini adalah G Minor Asli dan G Minor Harmonis. Tangganada Minor Asli adalah salah satu tangganada diatonik dengan interval antara not yang berurutan yaitu 1-1/2-1-1-1/2-1-1. Sedangkan, Tangganada Minor Harmonis adalah skala minor yang tersusun oleh delapan buah not, dengan interval antara not yang berurutan yaitu 1-1/2-1-1-1/2-11/2-1/2. Penggunaan kedua tangganada tersebut dalam lagu Aneuk Yatim dapat dilihat pada notasi berikut.

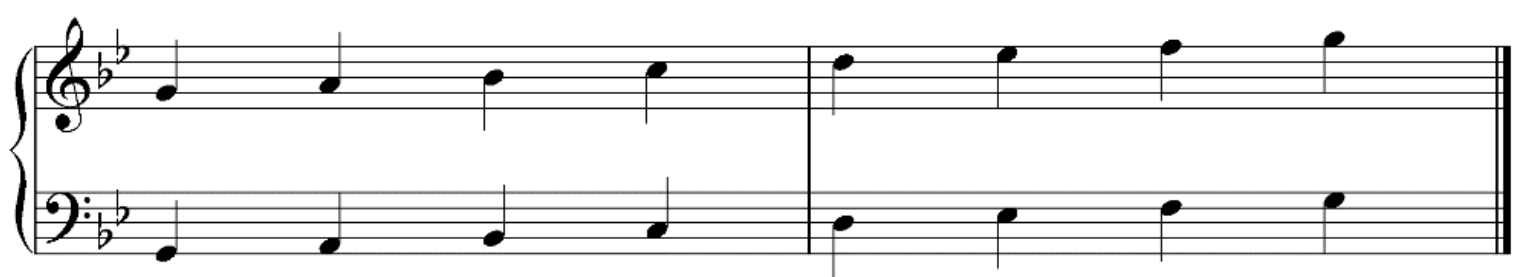

Notasi 13. Tangganada G minor Asli

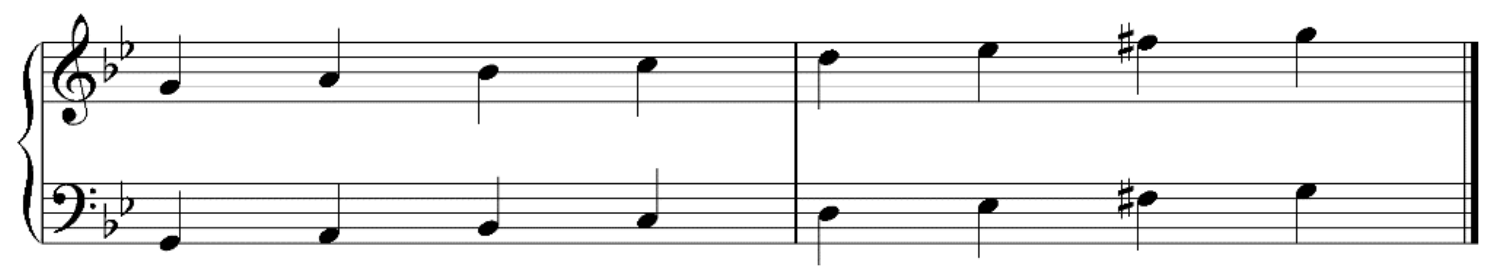

Notasi 14. Tangganada G minor Harmonis

\section{Kesimpulan}

Berdasarkan rumusan masalah dalam penelitian terhadap penggunaan instrumen musik dan harmoni iringan pada objek material yang dibantu pengamatan teori musik Barat untuk mengidentifikasi ilmu musik pada lagu Aneuk Yatim ciptaan Rafly Kande, dapat disimpulkan bahwa peran dari musik iringan menjadi faktor pendukung utama dalam instrumentasi dan perjalanan harmoni yang dipakai. Dari hasil penelitian ini dapat disimpulkan beberapa hal yaitu (1) penggunaan instrumen dalam lagu Aneuk Yatim terdiri dari acoustic guitar, keyboard, electric bass, dan drum set. Masing-masing instrumen tersebut mempunyai peran tersendiri dalam iringan lagu ini. Misalnya, acoustic guitar, keyboard, dan electric bass merupakan instrumen melodis dan instrumen harmonis yang digunakan sebagai instrumen dalam memainkan melodi pada interlude, serta instrumen harmonis yang memainkan akor sebagai iringan pada melodi pokok, dan (2) Harmoni iringan dan tangganada pada lagu Aneuk Yatim ini, seperti adanya penggunaan tangganada minor asli, dan minor harmonis, serta akor yang dipakai seperti akor I-IV-V (G-C-D). 
Dilihat dari perspektif objek formal dan material dalam penelitian ini diharapkan dapat menjadi referensi, serta dapat dijadikan sebagai acuan bagi penelitian selanjutnya. Penggunaan konsep maupun teori musik Barat, dapat dijadikan sebagai pembedah baik dalam analisis dan mengkaji bentuk dan struktur musik, pemakaian pengembangan melodi, pemakaian instrumen musik, serta harmoni musik yang dipakai. Dengan demikian, penelitian ini dapat menjadi pengembangan media pendidikan dalam mengimplementasikan ilmu musik dan menjadi bahan pembelajaran di akademisi.

\section{Referensi}

Abdul Rozak, Haria Nanda Pratama, \& Gusmanto, R. (2020). Analisis Melodi Pada Lagu Aneuk Yatim Ciptaan Rafly Kande. Besaung, 5(2), 123-128.

Elpasa, E., Ismunandar, I., \& Muniir, A. (N.D.). Kajian Musikologi Musik Iringan Tari Jepin Keris Karya Yuza Yanis Chaniago. Jurnal Pendidikan Dan Pembelajaran Khatulistiwa, 7(5).

Ferdian, R., Sinaga, F. S. S., \& Putra, A. D. (2021). Formulasi Musik Deret Dalam Penciptaan Komposisi Programa Berjudul Kupu-Kupu Terakhir. Tonika: Jurnal Penelitian Dan Pengkajian Seni, 4(1), 67-81.

Firnandez, R., Mering, A., \& Sanulita, H. (2014). Analisis Pola Ritme Musik Jepin Lembut Kecamatan Tebas Kabupaten Sambas (Suatu Tinjauan Musikologi). Jurnal Pendidikan Dan Pembelajaran Khatulistiwa, 4(12).

Frianto, A. (2012). Makna Pesan Sosial Dalam Lirik Lagu "Aneuk Yatim" Oleh Rafly Kande (Analisis Semiotika Tentang Makna Pesan Sosial Pada Lirik Lagu “Aneuk Yatim" Oleh Rafly Kande). Upn" Veteran" Yogyakarta.

Ghazali, I., \& Syahrani, A. (N.D.). Tinjauan Musikologi Lagu Sekapor Sireh Dalam Tradisi Penyambutan Di Keraton Amantubillah. Jurnal Pendidikan Dan Pembelajaran Khatulistiwa, 4(12).

Indrawan, A. (2018). Berbagi Musik Persembahan Untuk Sang Maha Guru. Bp Isi Yogyakarta.

Jamalus. (1988). Pengajaran Musik Melalui Pengalaman Musik. Proyek Pengembangan Lembaga Pendidikan.

Johnson, R., Huron, D., \& Collister, L. B. (2014). Music And Lyrics Interactions And Their Influence On Recognition Of Sung Words: An Investigation Of Word Frequency, Rhyme, Metric Stress, Vocal Timbre, Melisma, And Repetition Priming. Empirical Musicology Review, 9(1), 2-20. Http://Emusicology.Org/Article/View/3729

Leon Stein. (1979). Structure And Style: The Study And Analysis Of Musical Form. Summy Birchard Music.

Lestari, L. (2019). Pengembangan Bahan Ajar Berbasis Nilai Karakter Dalam Lirik Lagu Rafly Kande Untuk Siswa Kelas Viii Madrasah Tsanawiyah Swasta Geudubang Aceh, Kota Langsa. Unimed.

Mahendra, Y. E., Mering, A., \& Sanulita, H. (2016). Kajian Musikologi Komposisi Musik Iringan Tari Jepin Langkah Simpang Kota Pontianak. Jurnal Pendidikan Dan Pembelajaran Khatulistiwa, 5(4).

Moleong, L. J. (2021). Metodologi Penelitian Kualitatif. Pt. Remaja Rosdakarya. 
Prier, K. E. (1996). Ilmu Bentuk Musik. Pusat Musik Liturgi.

Rozak, A., Pratama, H. N., \& Gusmanto, R. (2021). Analisis Melodi Lagu Aneuk Yatim Ciptaan Rafly Kande. Besaung: Jurnal Seni Desain Dan Budaya, 5(2).

Rulam, A. (2014). Metode Penelitian Kualitatif. Ar-Ruzz Media.

Walidaini, B. (2020). Analisis Tekstual Koyunbaba Karya Carlo Domeniconi: Bentuk Dan Struktur Bagian I Moderato. Musikolastika, 2(2).

Widyanta, N. C. (2018). Antara Teori Formula Albert B Lord Dan Musikologi. Journal Of Music Science, Technology, And Industry, 1(1), 23-34. 